продукує інформацію, ефективно використовує IКТ в навчально-виховному процесі початкової школи.

\title{
Література
}

1. Барановська В. М. Змістова характеристика стану та проблем формування інформатичних компетентностей майбутніх учителів початкових класів [Електроний ресурс]/ В. М. Барановська // Науковий вісник Донбасу. - 2012. - № 4. - Режим доступу: http://nbuv.gov.ua/j-pdf/nvd_2012_4_19.pdf 2. Бахмат Н. Конкурентоспроможність учителя початкової школи в умовах інформатизації освіти / Н. Бахмат // Проблеми підготовки сучасного вчителя. - 2014. - № 9 (1). - С. 257-263. 3. Дедюхина А. А. Педагогические условия формирования информационной компетентности будущих учителей начальных классов / А. А. Дедюхина // Теория и практика образования в современном мире: материалы междунар. науч. конф. (г. Санкт-Петербург, февраль 2012 г.). - Санкт-Петербург : Реноме, 2012. - С. 280-284. 4. Кушнір Н. О. Модель підготовки майбутніх учителів початкових класів до навчання основ інформаційно-комунікаційних технологій / Н. О. Кушнір // Інформаційні технології в освіті. - 2013. - № 17. - С. 147-153. 5. Михайлюк А. Ю. Про деякі напрямки інформатизації вищої освіти в умовах сьогодення / А. Ю. Михайлюк, М. В. Сніжко, Л. М. Бігун // Вища освіта України. - 2009. - Додаток 4, том I (13). - С. 457463. б. Овчинникова М. В. Использование компьютерных технологий в подготовке учителей начальных классов [Электронный ресурс] / M. В. Овчинникова // Форум конференций МГЛУ.- Режим доступу: http://conference.mdpu.org.ua/index.php 7. Олефиренко Н. В. Проблемы подготовки учителя начальной школы к проектированию дидактических электронных ресурсов [Электронный ресурс] / Н. В. Олефиренко // Образовательные технологии. - №1. - $\quad$ С. 577-589. - $\quad$ Режим доступа: http://ifets.ieee.org/russian/ depository/v17_i1/pdf/16.pdf. 8. Петухова Л. С. Актуальні питання формування інформатичних компетентностей майбутніх учителів початкових класів / Л. Є. Петухова, О. В. Співаковський // Комп’ютер у школі та сім’ї. - 2011. - № 1. - С. 7-11. 9. Співаковський О. В. Інформаційно-комунікаційні технології в початковій школі : [навч.метод. посіб.] / О. В. Співаковський, Л. Є. Петухова, В. В. Коткова. - Херсон: Айлант, 2012. 385 с. 10. Суховірський О. В. Підготовка майбутнього вчителя початкової школи до використання інформаційних технологій : автореф. дис. на здобуття наукового ступеня канд. пед. наук : спец. 13.00.04 «Теорія і методика професійної освіти»/ О. В. Суховірський; Інститут педагогіки АПН України. - Київ, 2005. - 20 с.

УДК 373.3.015.3

Олена Павлик

\section{ДИДАКТИЧНІ УМОВИ ФОРМУВАННЯ ТВОРЧОЇ ОСОБИСТОСТІ В КОНТЕКСТІ КОМПЕТЕНТНІСНОЇ ОСВІТИ}

Павлик О. А. Дидактичні умови формування творчої особистості в контексті компетентнісної освіти.

У статті розглядаються особливості процесу становлення творчої особистості, розкриваються педагогічні умови ефективності досліджуваного процесу. Висвітлено специфіку розвитку творчої особистості з огляду на завдання компетентнісного підходу в освіті.

Ключові слова: творча особистість, процес формування творчої особистості, 
компетентнісний підхід в освіті, дидактичні умови.

Павлик Е. А. Дидактические условия формирования творческой личности в контексте компетентностного образования.

В статье рассматриваются особенности процесса становления творческой личности, раскрываются педагогические условия эффективности исследуемого процесса. Отражена специфика развития творческой личности с учётом задач компетентностного подхода в образовании.

Ключевые слова: творческая личность, процесс формирования творческой личности, компетентностный подход в образовании, дидактические условия.

Pavlyk O. A. Didactic conditions of the creative personality formation in the context of competent-based education.

In the article features of process of the creative personality formation are described, pedagogical conditions of efficiency of the studied process are shown. Specifics of the creative personality development taking into account problems of competence-based approach in education are examined.

Key words: the creative personality, the process of the creative personality formation, competence-based approach in education, didactic conditions.

Аналіз державних документів, що регулюють освітній процес, дозволяє стверджувати, що серед пріоритетів державної освітньої політики важливе місце належить формуванню компетентної творчої особистості. Так, серед завдань Дорожньої карти освітньої реформи 2015-2025 p.p. МОН України визначено розробку у 2018-2019 рр. Національного курикулуму загальної середньої освіти, що передбачає такі цілі навчального процесу, як: розвиток особистості учня, визначальними чинниками якої $\epsilon$ впевненість, успішність, реалізація свого потенціалу та місії в житті, формування ключових компетентностей, що забезпечуватимуть громадянську активність, ініціативність, творчість, уміння ставити цілі i ухвалювати рішення, самомотивацію, управління власним життям. При цьому компетентнісний підхід вимагає від учнів не лише певних знань, умінь і навичок, а й здатності до розв'язання нестандартних завдань. Проте на шляху реалізації поставлених завдань виникає багато суперечностей, зокрема щодо недостатньої підготовленості вчителя й учнів до творчої діяльності і необхідності щоденно долати різноманітні навчальні та життєві проблеми, котрі вимагають неординарності у ставленні до різних аспектів буття.

Мета статті полягає в розкритті сутності процесу становлення творчої особистості та визначенні дидактичних умов іiї формування в контексті компетентнісної освіти.

Як свідчить аналіз наукової літератури, проблема формування творчої особистості не $\epsilon$ новою. Зокрема, психолого-педагогічні аспекти формування творчої особистості розглядаються в дослідженнях Б. Ананьєва, В. Андреєва, Ю. Бабанського, . Беха, Д. Богоявленської, В. Загв'язінського, Н. Кузьміної, Г. Сіліної, С. Сисоєвої, Н. Лейтес, Г. Айзенка, Дж. Гілфорда, А. Маслоу, А. Олпорта, К. Роджерса, Д. Шеренберга та ін. На думку науковців, творча особистість - це особистість, в особистісному утворенні якої поєднується внутрішня потреба творити із розумінням суті справи, знаннями та вміннями, відповідною обдарованістю [5, c. 24]. Особистість творча - індивід, що володіє високим рівнем знань, потягом до нового, оригінального, уміє відкинути все звичайне, шаблонне.

На сьогодні мають місце різні концепції формування творчої особистості, які 
знаходять практичне втілення в різних педагогічних системах. Так, наприклад, в американській психології досить популярною $\epsilon$ інвестиційна теорія креативності Р. Стернберга. Сильна мотивація є головним джерелом творчості. Причому ця установка на творчість навіть важливіша, ніж інтелектуальна здібність до творчості [9, с. 84]. Окреслену теорію в російській психології підтримує Д. Богоявленська. Головною одиницею дослідження творчості дослідниця проголошує «інтелектуальну активність». Автор концепції вважає, що інтелектуальна активність інтегрує в собі інтелектуальні й особисті (мотиваційні) чинники розумової діяльності, але не зводиться ні до тих, ні до тих окремо. Розумові здібності складають фундамент інтелектуальної активності, але виявляються опосередковано, через мотиваційну структуру, яка або гальмує, або стимулює творчість [2, c. 147].

Прихильники когнітивної концепції формування творчої особистості розглядають взаємозалежність якостей творчої особистості та іiі когнітивної сфери. Так, у концепції М. Холодної основою особистості $є$ особлива організація індивідуального ментального досвіду. Розглядувана психологічна теорія $\epsilon$ фундаментом «збагачувальної моделі» розумового розвитку школярів. Основне завдання інтелектуального виховання у цій педагогічній системі - допомогти дитині збудувати свій власний ментальний світ. Процес викладання в контексті «збагачувальної моделі» перетворюється в особливого роду діяльність учителя, направлену не стільки на трансляцію знань і способів пізнання, скільки на «вибудовування» за допомогою певного навчального матеріалу арсеналу суб'єктивних засобів продуктивного інтелектуального ставлення до дійсності [10, с. 85].

Формування творчої особистості учня повинно передбачати не тільки посилений розвиток певних психічних процесів i творчих умінь, а й розвиток мотивів, характерологічних особливостей, які, інтегруючись 3 психічними процесами й творчими вміннями, зумовлюють здатність особистості до творчості. Саме тому, виходячи із концепцій визначення здібностей Б. Ананьєва, В. Шадрикова і професійних здібностей Б. Федоришина, для дослідження процесу формування творчої особистості учня до наукового обігу вводять поняття творчих можливостей учня.

Творчі можливості учня - це відносно самостійна, динамічна система творчих якостей його особистості, пов'язана з інтелектом, умовами розвитку, яка формується, розвивається та виявляється у творчій діяльності і забезпечує розвивальну взаємодію особистості 3 довкіллям [8, с. 43]. С. Сисоєва вважає, що творчі можливості особистості виявляються в їі творчій діяльності і відображають здатність особистості до нестандартних розв'язань стандартних завдань. За таких умов творчі можливості являють собою сукупність творчих якостей особистості, деякі з яких мають подвійну природу. 3 одного боку, вони природні, а 3 іншого, визначаються умовами розвитку, навчання і виховання. Тому, робить висновок науковець, модель творчої особистості учня повинна бути мультифакторною за своїм конструктом i відображати як природжене, так i надбане у структурі особистості учня [8, с. 53].

Творча активність, творчий потенціал дітей можна проаналізувати за такими трьома групами показників: ставлення дітей до творчості (їхнє захоплення, здатність «увійти» в уявні обставини, в умовні ситуації, щирість переживань); якість способів творчих дій (швидкість реакцій, винахідливість, комбінування знайомих елементів у нові поєднання, оригінальність способів дій); якість продукції (відбір характерних ознак, предметів, життєвих явищ, відображення їх у творчій діяльності) [1, с. 9].

Розвиток творчої особистості потребує відповідних умов, від яких залежить його 
ефективність, продуктивність виявів особистості як суб’єкта діяльності.

В. Рибалко пропонує використовувати поняття «формування особистості»у двох аспектах: формування особистості як їі розвиток, його процес і результат та педагогічний підхід, що передбачає виявлення того, що і як має бути сформовано в особистості, щоб вона відповідала вимогам, які висуває до неї суспільство [6, с. 9].

3 огляду на сучасні вимоги компетентнісного підходу в українській освіті XXI століття навчальний процес має бути спрямований насамперед на формування та розвиток ключових (базових) i предметних компетенцій, становлення діяльної компетентної особистості. Причому, на думку О. Савченко, компетентності потрібно формувати через спеціально підготовлений зміст, навчальні технології й розвивально збагачене навчальне середовище, яке має характеризуватися такими ознаками: відкритістю, цілісністю, емоційною комфортністю, суб'єктивністю навчальної взаємодії [7, с. 143].

Дидактична взаємодія «вчитель - учень» - важливий чинник пізнавальної активності, самостійності учнів. Оскільки дитина від природи своєї - активний дослідник зовнішнього світу, навчання має будуватися на принципі самодіяльності, активності та продуктивної творчості. Це має бути школа радості, взаєморозуміння, творчого співробітництва дітей i дорослих, школа гуманізму і духовності.

У свою чергу процес формування творчої особистості учня як суб'єкта творчих соціальних відносин і продуктивної творчої діяльності за своєю суттю є педагогічним управлінням розвитком потенційних творчих можливостей дитини, формуванням у неї таких творчих якостей, які забезпечують успішність у творчій діяльності, індивідуальне становлення особистості учня як суспільно активної. Формування творчої особистості учня у навчально-виховному процесі слід розглядати як процес фасилітації, тобто як створення умов з метою полегшення, сприяння, стимулювання, активізації розвитку творчих можливостей учнів.

Серед дидактичних умов розвитку творчих здібностей школярів у процесі навчальної діяльності можна виокремити такі: педагогічне стимулювання, застосування психологопедагогічних технологій, системність роботи з учнями в умовах творчо-розвивального середовища.

Педагогічне стимулювання розвитку творчих здібностей здійснюється на основі особистісно зорієнтованого характеру взаємодії вчителя з учнями. Необхідність реалізації цієї умови продиктована сучасними суспільними пріоритетами. Тенденції особистісної орієнтації розвитку системи освіти підкріплені результатами досліджень сучасних вітчизняних психологів (Г. Балл, Г. Костюк, С. Максименко, В. Рибалка, В. Семиченко та ін.) i педагогів (І. Бех, І. Зязюн, В. Кремень, О. Пєхота, С. Сисоєва та ін.). Особистісно зорієнтована взаємодія учителя й учня передбачає пріоритетним такий засіб навчання $\mathrm{i}$ виховання, як спілкування, в якому не існує різкої полярності позицій учня й учителя, перетворення навчально-виховного процесу на взаємодію. Це сприяє стимулюванню активності, самостійності, ініціативності дітей, поєднанню творчої свободи і спрямування діяльності учнів, емоційності та виразності спілкування з проявами поваги і доброзичливості учасників педагогічного процесу.

Застосування психолого-педагогічних технологій, що забезпечують самостійну активність учнів у процесі творчої діяльності. Виконання цієї умови має гарантувати позитивну мотивацію творчої діяльності школярів і надавати дієвий арсенал психологопедагогічних стимулів, які спрямовуватимуть активність учнів у необхідному напрямку. Такі психолого-педагогічні технології повинні враховувати вікові особливості, забезпечувати 
оптимальні умови для самовираження учнів, спиратися на особистісно значущий для учнів матеріал, залучати їхні емоції до процесу творчості, спонукати учнів у процесі творчої діяльності відображати свій чуттєвий досвід у повному обсягу, надавати можливість самостійно творити.

Системність роботи з учнями в умовах творчо-розвивального середовища. У повсякденному житті знання, які використовуються, тісно переплітаються одне з одним, утворюючи єдину систему. Тому учень повинен бачити предмет чи явище системно: в єдності зі зв'язками, в які він вступає. Максимально позитивні, сприятливі умови для розвитку дитячої творчості, для виховання творчої особистості створює розвивальне середовище (Л. Божович, О. Дяченко, О. Кононко, В. Кудрявцев, С. Кулачківська, А. Петровський та ін.). Системність роботи в умовах творчо-розвивального середовища можна забезпечити, урахувавши необхідність розвитку основних психічних процесів дитини, засобом формування яких поставатиме діяльність. Н. Бондаренко уважає, що така система повинна передбачати розвиток процесів сприймання, здатності до уявлення, ейдетичних можливостей дитячого мислення, уміння переборювати стереотипи, формування навичок асоціативного і гнучкого мислення тощо [3, с. 23].

Результативний творчий розвиток забезпечується також активною, емоційно забарвленою творчою діяльністю, оскільки емоція - це почуття, що мотивує, організовує і спрямовує сприймання, мислення і дії. Збагачення емоційно-чуттєвого досвіду учнів у процесі навчання може бути забезпечене через їх емоційну підготовку, емоційну насиченість навчального матеріалу та методів навчання, незвичність способу постановки завдання, чіткість і динамічність переходу від одного виду роботи до іншого, вчасний перехід від пояснення до практичних дій учнів.

Одним із найважливіших чинників творчого розвитку дітей є створення відповідних умов, що сприяють формуванню їх творчих здібностей:

-створення середовища, щуо випереджає розвиток дітей. Необхідно, наскільки це можливо, заздалегідь оточити таким середовищем і такою системою відносин, які б стимулювали найрізноманітнішу творчу діяльність і поволі розвивали б у дитині саме те, що у відповідний момент здатне найбільш ефективно розвиватися;

-надання дитині свободи у виборі діяльності, у чергуванні видів роботи, у тривалості занять однією якою-небудь справою, у виборі способів діяльності тощо. Тоді бажання дитини, iii інтерес, емоційний підйом стануть надійною гарантією того, що більше напруження розуму не призведе до перевтоми, і буде дитині корисним. Але надання дитині такої свободи не виключає, а, навпаки, передбачає ненав'язливу, розумну, доброзичливу допомогу дорослих. Найголовніше - не перетворювати свободу на вседозволеність, але на допомогу, на підказку.

Загальновідомий факт, що для творчості необхідні комфортні психологічні умови $i$ наявність вільного часу, тепла дружня атмосфера в сім’ї й дитячому колективі. Дорослі повинні створити безпечну психологічну базу для повернення дитини з творчого пошуку і власних відкриттів. Важливо постійно стимулювати дитину до творчості, виявляти співчуття до іiі невдач, терпляче ставитися навіть до дивних ідей, невластивих реальному життю. Потрібно вилучити з ужитку зауваження та засудження.

Для розвитку творчої особистості школяра необхідно дотримуватись також таких дидактичних умов:

Уміння виходити за межі свого предмета. Кожний навчальний предмет містить загальні і спеціальні методи, що зумовлені специфікою його сутності. Наприклад, в 
українській мові використовують такі спеціальні методи, як читання, письмо, словникова робота й інші, а в природознавстві такі, як спостереження, досліди. Якщо використати метод спостереження або досліду в навчанні української мови, то це внесе певну новизну у виклад учням навчального матеріалу. Це активізує спосіб отримання ними знань, зробить його незвичайним, цікавим, допоможе підійти до вивчення чогось нестандартно і творчо. У результаті це впливатиме на творчий розвиток дітей, оскільки подібний вихід за межі предмета може стимулювати дитячу фантазію та мислення.

Стимулювати емоційно-позитивний вплив на мотиваџійну сферу школярів. Кожний урок має підкріплюватися позитивними емоціями. Це сприятиме позитивному налаштуванню дітей до уроку, формуватиме та зберігатиме зацікавленість учнів у навчанні, бажання до самоосвіти та попереджуватиме стомлюваність. Позитивні емоції сприятимуть розвитку творчої особистості учнів. Реалізації емоційно-позитивного впливу сприятимуть прийоми, які наводить В. Ковальова: урахування інтересів та нахилів учнів, підтримування успіхів учнів у навчально-виховному процесі, схвалення здорового суперництва, застосування різноманітних ефективних методів організації пізнавальної діяльності, створення умов для обрання оптимальних форм діяльності на уроці, надання учневі шансу виявитися, співпереживальна критика [4, с. 29].

Використання різноманітних видів діяльності на уроизі. Різноманітні види діяльності сприяють всебічному розвитку учнів, зменшують стомлюваність їх на уроці, роблять заняття цікавими, посилюють інтерес учнів до навчання. Часта зміна видів діяльності на уроках задовольняє природну потребу школярів у русі [7, с. 155-165]. Якщо учитель зможе правильно визначити необхідну кількість завдань, то це обов'язково впливатиме на розвиток не тільки розумових здібностей учнів, а і творчих.

Знання, які отримують учні на урочі, повинні бути пов'язані із життям та особистим досвідом учнів. Діти мають відчути на практиці необхідність використання нових знань і можливість їх застосувати. На уроках результатом таких знань є, наприклад, гармонійний розвиток мовленнєвої діяльності у всіх її видах, уміння вчитися, організовувати свою навчальну діяльність, мати свою власну позицію в обговоренні якогось питання тощо. Це виявляється у знаннях учнів 3 предметів і в умінні їх застосування, виконання різноманітних завдань, творчих вправ, розігрування ситуацій тощо.

Залучення учнів до творчої діяльності через інтегровані творчі завдання, які надають можливість розглянути нові знання з різних сторін, розширюють можливості використання різноманітних завдань на уроках для засвоєння отриманих знань. Це дає змогу більш творчо підійти до вивчення теми, у результаті чого будуть розвиватися не тільки пізнавальні можливості дітей, удосконалюватися їх знання, а й здійснюватиметься творчий розвиток усіх учнів. Результатом виконання інтегрованих завдань можуть бути власні вірші дітей, твори, малюнки, колажі, аплікації та інше. У такий спосіб у дітей буде розвиватися їхня творча уява та мислення.

Отже, формування особистості - це динамічний процес, що відбувається під впливом різноманітних факторів, серед яких важливе місце посідає творча діяльність і особистість учителя. Творча особистість розвивається у творчій діяльності і спілкуванні за відповідних умов. Переорієнтація навчально-виховного процесу на формування творчої особистості реалізується за умови дотримання таких дидактичних умов розвитку творчих здібностей: педагогічного стимулювання розвитку творчих здібностей на основі особистісно зорієнтованого характеру взаємодії учителя з учнями; застосування психолого-педагогічних технологій, що забезпечують самостійну активність учнів у процесі творчої діяльності; 
системності творчої роботи з учнями.

Учитель має виходити за межі свого предмета, стимулювати емоційну сферу дітей, здійснювати емоційно-позитивний вплив, мотивувати діяльність, використовувати різноманітні види діяльності на уроці, пов'язувати знання 3 життєвим досвідом дітей та залучати дітей до творчої діяльності через інтегровані творчі завдання.

\section{Література}

1. Біла І. Феномен дитячої творчості / І. Біла // Дошкільне виховання. - 2011. - № 1. С. 7-11. 2. Богоявленская Д. Б. Интеллектуальная активность как проблема творчества / Д. Б. Богоявленская. - Ростов-на-Дону: Изд-во Ростовского университета, 1983. - 172 с. 3. Бондаренко Н. Про формування творчої особистості молодшого школяра засобами слова / Н. Бондаренко // Початкова школа. - 1998. - № 9. - С. 22-24. 4. Ковальова В. І. Інтеграція навчального процесу як чинник розвитку пізнавальної активності учнів / В. І. Ковальова // Початкове навчання та виховання. - 2012. - № 16-18. - С. 27-34. 5. Пермяков О. А. Короткий термінологічний словник 3 педагогіки / О.А. Пермяков. - Кривий Ріг : Видавничий дім, 2007. - 116 с. 6. Рибалка В. В. Поняття про творчість, творчу особистість та особистісний підхід до вивчення i розвитку творчого потенціалу молоді // Рибалка В. В. Психологія розвитку творчої особистості. - Київ, 1995. - С. 5-24. 7. Савченко О. Я. Дидактика початкової освіти: [підручник] / Олександра Яківна Савченко. - Київ : Грамота, 2012. - 504 с. 8. Сисосва С. О. Основи педагогічної творчості вчителя / Світлана Олександрівна Сисоєва. - Київ : ІСДОУ, 1994. - 112 с. 9. Стернберг Р. Практический интеллект / Р. Стернберг. - Санкт-Петербург : Питер, 2002.- 272 с. 10. Холодная М. А. Психология интеллекта / М. А. Холодная. - Санкт-Петербург : Питер, 2002. $-272 \mathrm{c}$.

\section{СОЦІОКУЛЬТУРНИЙ ПІДХІД ДО НАВЧАННЯ АНГЛІЙСЬКОЇ МОВИ У ВИЩОМУ НАВЧАЛЬНОМУ ЗАКЛАДІ}

Покорна Л. М. Соціокультурний підхід до навчання англійської мови у вищому навчальному закладі.

У статті аналіз особливостей формування комунікативної компетенції дозволив виокремити соціокультурну компетенцію майбутніх учителів англійської мови в окремий компонент комунікативної компетенції та розглянути їі як цілісну систему, до якої входить країнознавча компетенція, лінгвокраїнознавча компетенція та соціолінгвістична компетенції.

Ключові слова: комунікативна компетенція, соціокультурна компетенція, країнознавча компетенція, лінгвокраїнознавча компетенція, соціолінгвістична компетенція.

Покорная Л. Н. Социокультурный подход к изучению английского языка в высшем учебном заведении.

В статье анализ особенностей формирования коммуникативной компетенции позволил выделить социокультурною компетенцию будущих учителей английского языка в отдельный компонент и рассмотреть её как целостную систему, в которую входят страноведческая компетенция, лингвострановедческая компетенция и социолингвистическая компетенции.

Ключевые слова: коммуникативная компетенция, социокультурная компетенция, 